\title{
Doctors Rule: An Analysis of Health Ministers' Diaries in Australia
}

\author{
Katherine Cullerton ${ }^{1, *(D)}$, Tom White ${ }^{2}$ (D) and Amanda Lee ${ }^{1}$ (D) \\ 1 School of Public Health, Faculty of Medicine, University of Queensland, 288 Herston Road, \\ Herston, QLD 4006, Australia \\ 2 MRC Epidemiology Unit, University of Cambridge School of Clinical Medicine, Box 285, \\ Institute of Metabolic Science, Cambridge Biomedicine Campus, Cambridge CB2 0QQ, UK \\ * Correspondence: k.cullerton@uq.edu.au
}

Received: 29 May 2019; Accepted: 5 July 2019; Published: 9 July 2019

check for updates

\begin{abstract}
Limited progress in nutrition policy action is often blamed on the close relationships the food industry has with health policy decision-makers. This analysis sought to examine this belief through the analysis of health ministers' diaries. Entries were downloaded from health ministers' diaries from two states in Australia from January 2013 to June 2018. Entries were coded according to which interest group met with the minister or whether general parliamentary business was undertaken. Coding was also undertaken for any meeting topics related to nutrition policy. Analysis of health ministers' diaries found that the food industry has limited documented interaction with the two state health ministers in Australia. Instead, medical associations, private hospitals and health services, and sporting associations (rugby league associations) had the most interactions with health ministers. Poor representation was seen on nutrition issues, and there was an apparent lack of nutrition advocates interacting with the health ministers. There are opportunities for nutrition advocates to increase their level of interaction with state health ministers. This could include building alliances with medical associations, as they are in a powerful position, to advocate directly to health ministers. Health ministers' diaries can provide valuable insights into who is meeting officially with ministers. However, there are also limitations with the dataset.
\end{abstract}

Keywords: nutrition policy; advocacy; food industry; public health; health policy; lobbying; policy making

\section{Introduction}

There are many ways interest groups can attempt to influence public policy. Strategies can include engaging with the media, shaping the evidence base, making donations to political parties and grassroots campaigns [1,2]. While these strategies are important, direct access to policymakers seems to play a significant role in influencing public policy, particularly for policy that is contested [3,4]. Gaining direct access to policymakers allows interest groups to develop relationships with them, deliver their arguments more effectively and identify potential policy leverage points [2].

A particularly contested health policy area in many countries is public health nutrition policy $[5,6]$. This has certainly been the case in Australia, where, over the past decade, there has been a distinct lack of political support for evidence-based nutrition policy actions, such as fiscal and regulatory interventions [4,7]. Instead, the government has supported education-based campaigns and voluntary initiatives involving the food industry [8]. It has been proposed that this inaction in nutrition policy is due to the opposing power of food industry interest groups [1,7,9]. The power and influence of the food industry was recently demonstrated in a network analysis of national nutrition policy stakeholders in Australia [4]. This analysis highlighted that the food industry had the greatest number of direct 
access points to nutrition policymakers than any other interest group. However, limited investigation of interest groups and their interactions with policymakers has occurred at the state jurisdictional level in Australia.

Examining the interactions of interest groups at a state level is important, as Australia is a federation of six states and two self-governing territories, each of which have their own constitutions and laws. However, certain areas of law-making require both the state and national levels of government to work together to achieve policy outcomes [7]. This can give states a high degree of power when considering nutrition policy.

In January 2013, the state of Queensland (QLD) was the first jurisdiction in Australia to require government ministers to release their diaries on a monthly basis [10] and the state of New South Wales (NSW) followed in July 2014, although with quarterly releases [11]. While this was an important step toward transparency, in both jurisdictions, there is no requirement to disclose information relating to personal, electorate or party-political matters, social or public functions or events, or matters for which there is an over-riding public interest against disclosure [10,11].

The diaries are available for two jurisdictions which represent just over half of the Australian population (NSW: 7,955,900; QLD: 4,999,700) [12]. Further information on these states and the political parties in Australia is included in Box 1. Analysing the health ministers' diaries from these two states provided unique insight into which interest groups were interacting with health ministers generally, and in particular, with respect to nutrition policy.

Box 1. The jurisdictions of New South Wales and Queensland.

The jurisdictions of New South Wales and Queensland.
New South Wales is considered the most powerful state in Australia, as it has the largest population and
economy [13]. Furthermore, it is a manufacturing state and many national and international companies have
their headquarters located there. QLD is known for agriculture, mining and tourism and is the third wealthiest
state in Australia [13]. Since ministerial diaries have been recorded, QLD has had a change of governing political
party, going from the Liberal-National Party (centre-right liberal conservative) to the Australian Labour Party
(centre-left), whereas in NSW the Liberal Party (centre-right liberal conservative) has been the governing party
throughout. The changes in political party and ministers are included in the table below (Table 1). During this
period, NSW appointed an Assistant Health Minister to support the Health Minister. Assistant Ministers are
appointed to support Ministers in prioritising work to facilitate public access to the executive and to enable the
bureaucracy to have an ongoing point of contact [14]. They do not attend executive council or cabinet meetings.
This position was abolished in NSW in January 2017.

Table 1. Changes in health ministers in New South Wales and Queensland (2013-2018).

\begin{tabular}{|c|c|c|c|c|c|c|}
\hline & 2013 & 2014 & 2015 & 2016 & 2017 & 2018 \\
\hline $\begin{array}{l}\text { QLD Health } \\
\text { Min }\end{array}$ & L. Springborg ${ }^{a}$ & L. Springborg ${ }^{a}$ & C. Dick ${ }^{b}$ & C. Dick ${ }^{b}$ & C. Dick ${ }^{b}$ & S. Miles ${ }^{b}$ \\
\hline $\begin{array}{c}\text { NSW Health } \\
\text { Min }\end{array}$ & & J. Skinner ${ }^{a}$ & J. Skinner a & J. Skinner a & B. Hazzard ${ }^{a}$ & B. Hazzard ${ }^{\text {a }}$ \\
\hline $\begin{array}{c}\text { NSW } \\
\text { Assistant } \\
\text { Health Min }\end{array}$ & & $\begin{array}{l}\text { J. Rowell (also Minister } \\
\text { for mental health) }^{\mathrm{a}}\end{array}$ & $\begin{array}{l}\text { P. Goward (also } \\
\text { Minister for mental } \\
\text { health, women \& } \\
\text { medical research) }\end{array}$ & $\begin{array}{l}\text { P. Goward (also } \\
\text { Minister for mental } \\
\text { health, women \& } \\
\text { medical research) }\end{array}$ & & \\
\hline
\end{tabular}

\section{Materials and Methods}

Ministers' diaries from January 2013 to June 2018 were downloaded as PDFs from the relevant government websites and data were extracted into an excel spreadsheet. Diary entries were coded according to which interest group was meeting with the minister or if general parliamentary/portfolio business was undertaken. These were broadly classified into four categories:

- advocacy: including not-for-profit groups, charities, citizen groups and professional associations, 
- business: including for-profit organisations, businesses and their peak bodies,

- university: public universities or public research institutions, and

- general business: any standard parliamentary/portfolio business, community electorate meetings, etc.

Several entries were documented as 'business receptions'; for the QLD ministers, the diaries generally detailed each company who came to these receptions. When 25 companies or fewer were present, each company was coded individually. When more than 25 companies attended these events, they were coded as 'general business receptions', and companies were not coded individually, as potential one-on-one time with the minister would be decreased.

Once each diary entry was coded individually and within the four categories above, the individual entries were collated into general codes around their professional focus, for example, bank, food company, medical association, and cancer organisation. This coding framework was applied to all the diary entries. The initial coding and development of the coding framework was conducted by one investigator and then discussed with the co-authors until consensus was reached. The first author then deductively coded all the diary entries using the agreed framework. Coding was also undertaken for meeting topics specifically around nutrition. Ten percent of the diary entries were double-coded by an independent research assistant.

\section{Results}

In total, 5025 diary entries were coded. QLD health ministers' diaries covered a period of 63 months and included 3926 diary entries. NSW health ministers' diaries covered 48 months and included 586 diary entries, while the diaries of the Assistant Health Minister for NSW covered 31 months and included 513 diary entries. The two jurisdictions record diary entries differently, with the QLD ministers' diaries recording all appointments including general business, and the diaries of the NSW Health Minister and Assistant Minister including limited records of these appointments. To ensure comparability, appointments related to general business were removed. However, it is interesting to note that in the QLD ministers' diaries, the majority of entries related to general portfolio and electoral business, whereas meetings with interests groups made up only $27 \%$ of all diary entries.

The average number of appointments ministers spent with the different interest groups per month can be seen in Table 2.

Table 2. Average numbers of recorded appointments with interest groups in ministers' diaries, per month (January 2013-June 2018).

\begin{tabular}{ccccc}
\hline Minister & Time Period & $\begin{array}{c}\text { Advocacy } \\
\text { (Number of } \\
\text { Appointments/Month) }\end{array}$ & $\begin{array}{c}\text { Business } \\
\text { (Number of } \\
\text { Appointments/Month) }\end{array}$ & $\begin{array}{c}\text { Universities } \\
\text { (Number of } \\
\text { Appointments/Month) }\end{array}$ \\
\hline $\begin{array}{c}\text { Health Minister } \\
\text { QLD (LNP) }\end{array}$ & 24 months & 9.6 & 5.5 & 1.3 \\
\hline $\begin{array}{c}\text { Health Minister } \\
\text { QLD (ALP) }\end{array}$ & 39 months & 11.3 & 5.1 & 1.3 \\
\hline $\begin{array}{c}\text { Health Minister } \\
\text { NSW }\end{array}$ & 48 months & 6.0 & 4.1 & 1.8 \\
\hline $\begin{array}{c}\text { Assistant Health } \\
\text { Minister NSW }\end{array}$ & 31 months & 10.7 & 2.6 & 1.7 \\
\hline
\end{tabular}

According to the diaries, the QLD health ministers, regardless of political party, spent considerably more time interacting with advocacy and business groups than the NSW Health Minister. This is even more pronounced for the ALP QLD Health Minister who, on average, interacted with advocacy groups and business representatives almost twice as frequently as the NSW Health Minister. 
Doctors Rule

For advocacy groups, it was clear that across political parties and states, medical associations were dominant in interactions with health ministers. This was particularly evident for the 'doctors' union', the Australian Medical Association (AMA) (Table 3). Rates of interactions between medical associations and the ministers were higher than any other group. Other medical associations that were highly represented across all ministers' diaries were the Rural Doctors Association $(n=23)$, the Royal Australasian College of Surgeons $(n=16)$ and the Royal Australian and New Zealand College of Psychiatrists $(n=12)$.

Table 3. Top recorded advocacy interactions in health ministers' diaries (January 2013-June 2018) *

\begin{tabular}{|c|c|c|c|}
\hline $\begin{array}{l}\text { Health Minister QLD } \\
\text { (LNP) } 24 \text { Months }\end{array}$ & $\begin{array}{l}\text { Health Minister QLD } \\
\text { (ALP) } 39 \text { Months }\end{array}$ & $\begin{array}{l}\text { Health Minister NSW } \\
\text { (LP) } 48 \text { Months }\end{array}$ & $\begin{array}{c}\text { Assistant Health } \\
\text { Minister NSW (LP) } \\
31 \text { Months }\end{array}$ \\
\hline $\begin{array}{l}\text { Medical association } \\
(n=62, \mathrm{AMA}=28)\end{array}$ & $\begin{array}{l}\text { Medical association } \\
(n=56, \mathrm{AMA}=24)\end{array}$ & $\begin{array}{l}\text { Medical association } \\
(n=68, \mathrm{AMA}=21)\end{array}$ & $\begin{array}{l}\text { Mental health } \\
\text { organisations } \\
\quad(n=53)\end{array}$ \\
\hline $\begin{array}{l}\text { Mental health } \\
\text { organisations } \\
\quad(n=15)\end{array}$ & $\begin{array}{l}\text { Workers unions } \\
\qquad(n=36)\end{array}$ & $\begin{array}{l}\text { Cancer organisations } \\
\qquad(n=28)\end{array}$ & $\begin{array}{c}\text { Homelessness } \\
\text { organisations } \\
(n=40)\end{array}$ \\
\hline $\begin{array}{l}\text { Indigenous organisations } \\
\qquad(n=13)\end{array}$ & $\begin{array}{l}\text { Indigenous organisations } \\
\qquad(n=35)\end{array}$ & $\begin{array}{l}\text { Citizen groups } \\
\quad(n=17)\end{array}$ & $\begin{array}{l}\text { Drug \& alcohol } \\
\text { organisations } \\
\quad(n=36)\end{array}$ \\
\hline $\begin{array}{l}\text { Cancer organisations } \\
\qquad(n=11)\end{array}$ & $\begin{array}{l}\text { Nurses' union } \\
\quad(n=28)\end{array}$ & $\begin{array}{l}\text { Workers unions } \\
\qquad(n=16)\end{array}$ & $\begin{array}{c}\text { Domestic violence } \\
\text { organisations } \\
(n=20)\end{array}$ \\
\hline $\begin{array}{l}\text { Nurses' union } \\
\quad(n=11)\end{array}$ & $\begin{array}{l}\text { Mental health } \\
\text { organisations } \\
\quad(n=19)\end{array}$ & $\begin{array}{l}\text { Nurses' union } \\
\quad(n=10)\end{array}$ & $\begin{array}{l}\text { Community services } \\
\text { charities } \\
(n=18)\end{array}$ \\
\hline $\begin{array}{l}\text { Citizen groups } \\
\quad(n=10)\end{array}$ & $\begin{array}{l}\text { Youth organisations } \\
\qquad(n=16)\end{array}$ & $\begin{array}{l}\text { Paramedics } \\
\quad(n=10)\end{array}$ & $\begin{array}{c}\text { Medical } \\
(n=15, \text { AMA = 2) }\end{array}$ \\
\hline $\begin{array}{l}\text { Emergency Medicine } \\
\text { Foundation } \\
(n=6)\end{array}$ & $\begin{array}{l}\text { Multicultural } \\
\text { organisations } \\
\quad(n=14)\end{array}$ & $\begin{array}{l}\text { Children/youth charities } \\
\qquad(n=10)\end{array}$ & $\begin{array}{l}\text { Anti-windfarm groups } \\
\text { or individuals } \\
(n=14)\end{array}$ \\
\hline $\begin{array}{l}\text { Hospital Foundation } \\
\qquad(n=6)\end{array}$ & $\begin{array}{l}\text { Citizen groups } \\
\quad(n=13)\end{array}$ & $\begin{array}{l}\text { Heart disease } \\
\text { organisations } \\
\quad(n=7)\end{array}$ & $\begin{array}{l}\text { Council of Social Services } \\
\qquad(n=13)\end{array}$ \\
\hline $\begin{array}{c}\text { Royal Flying Doctors } \\
\text { Service } \\
(n=6)\end{array}$ & $\begin{array}{l}\text { Hospital Foundations } \\
\qquad(n=13)\end{array}$ & $\begin{array}{l}\text { Indigenous organisations } \\
\qquad(n=6)\end{array}$ & $\begin{array}{l}\text { Indigenous organisations } \\
\qquad(n=8)\end{array}$ \\
\hline $\begin{array}{l}\text { Workers unions } \\
\quad(n=6)\end{array}$ & & $\begin{array}{l}\text { Disability organisations } \\
\qquad(n=6)\end{array}$ & \\
\hline
\end{tabular}

For business groups, private hospitals topped interactions with the QLD Health Minister when the LNP were in power (Table 4). In NSW, private health care services had the highest number of interactions with the Health Minister, followed by private hospitals. Conversely, state and national associations representing a popular code of football in Australia (Rugby League) had the greatest interaction with the QLD Health Minister when Labour was in power. 
Table 4. Top recorded business interactions in health ministers' diaries (January 2013-June 2018) *.

\begin{tabular}{|c|c|c|c|}
\hline $\begin{array}{l}\text { Health Minister QLD } \\
\text { (LNP) } 24 \text { Months }\end{array}$ & $\begin{array}{l}\text { Health Minister QLD } \\
\text { (ALP) } 39 \text { Months }\end{array}$ & $\begin{array}{l}\text { Health Minister NSW } \\
\text { (LP) } 48 \text { Months }\end{array}$ & $\begin{array}{l}\text { Assis Health Minister } \\
\text { NSW (LP) } 31 \text { Months }\end{array}$ \\
\hline $\begin{array}{l}\text { Private Hospitals } \\
\qquad(n=16)\end{array}$ & $\begin{array}{l}\text { Rugby League } \\
\qquad(n=17)\end{array}$ & $\begin{array}{l}\text { Private health care } \\
\text { services } \\
(n=28)\end{array}$ & $\begin{array}{l}\text { Pharmaceutical } \\
\text { companies } \\
(n=15)\end{array}$ \\
\hline $\begin{array}{l}\text { Aged Care } \\
\quad(n=9)\end{array}$ & $\begin{array}{c}\text { Global } \\
\text { accounting/consulting } \\
\text { firms } \\
(n=13)\end{array}$ & $\begin{array}{l}\text { Private Hospitals } \\
\qquad(n=22)\end{array}$ & $\begin{array}{c}\text { Small } \\
\text { consultancy/investment } \\
\text { firms } \\
(n=10)\end{array}$ \\
\hline $\begin{array}{l}\text { Infrastructure company } \\
\qquad(n=9)\end{array}$ & $\begin{array}{l}\text { Pharmacy guild } \\
\qquad(n=12)\end{array}$ & $\begin{array}{l}\text { Medical devices } \\
\qquad(n=15)\end{array}$ & $\begin{array}{l}\text { Private disability/mental } \\
\text { health companies } \\
(n=6)\end{array}$ \\
\hline $\begin{array}{l}\text { Biotech company } \\
\qquad(n=6)\end{array}$ & $\begin{array}{l}\text { Property company } \\
\qquad(n=11)\end{array}$ & $\begin{array}{l}\text { Pharmaceutical } \\
\text { companies } \\
(n=11)\end{array}$ & $\begin{array}{l}\text { Construction/building } \\
\text { companies } \\
(n=5)\end{array}$ \\
\hline $\begin{array}{l}\text { Property company } \\
\qquad(n=6)\end{array}$ & $\begin{array}{l}\text { General business } \\
\text { receptions } \\
(n=10)\end{array}$ & $\begin{array}{l}\text { IT companies } \\
\quad(n=8)\end{array}$ & $\begin{array}{l}\text { Rugby League } \\
\qquad(n=3)\end{array}$ \\
\hline $\begin{array}{c}\text { Private health care } \\
\text { services } \\
(n=5)\end{array}$ & $\begin{array}{l}\text { Biotech company } \\
\qquad(n=8)\end{array}$ & $\begin{array}{l}\text { Pharmacy guild } \\
\qquad(n=8)\end{array}$ & $\begin{array}{l}\text { Clean energy companies } \\
\qquad(n=3)\end{array}$ \\
\hline $\begin{array}{l}\text { Construction company } \\
\qquad(n=5)\end{array}$ & $\begin{array}{l}\text { Taiwan business } \\
\text { representatives } \\
\quad(n=8)\end{array}$ & $\begin{array}{c}\text { Global } \\
\text { accounting/consulting } \\
\text { firms } \\
(n=8)\end{array}$ & $\begin{array}{l}\text { Marketing/communication } \\
\text { companies } \\
(n=3)\end{array}$ \\
\hline $\begin{array}{c}\text { Global } \\
\text { accounting/consulting } \\
\text { firms } \\
(n=5)\end{array}$ & $\begin{array}{l}\text { Aged Care } \\
\quad(n=7)\end{array}$ & $\begin{array}{l}\text { Banks } \\
(n=7)\end{array}$ & $\begin{array}{l}\text { Chamber of Commerce } \\
\qquad(n=3)\end{array}$ \\
\hline $\begin{array}{l}\text { Mining companies } \\
\qquad(n=4)\end{array}$ & $\begin{array}{l}\text { Law firms } \\
\quad(n=7)\end{array}$ & $\begin{array}{l}\text { Law firms } \\
\quad(n=7)\end{array}$ & $\begin{array}{l}\text { Small business owner } \\
\qquad(n=3)\end{array}$ \\
\hline $\begin{array}{l}\text { 3rd party lobbyists } \\
\qquad(n=4)\end{array}$ & $\begin{array}{l}\text { Pharmaceutical } \\
\text { companies } \\
(n=7)\end{array}$ & $\begin{array}{l}\text { Finance companies } \\
\qquad(n=7)\end{array}$ & $\begin{array}{l}\text { Local sports clubs } \\
\qquad(n=3)\end{array}$ \\
\hline
\end{tabular}

${ }^{*} n=$ total number of advocacy-related diary entries a Minister had during the period of time they held a health portfolio.

Very few interest groups met with the health ministers specifically regarding nutrition policy issues (Table 5). Of the 5,025 interactions documented, only 16 related specifically to nutrition issues and three of those included no interest group representation, instead involving only the Health Minister and departmental staff. Only one interaction from the food industry (Australian Beverages Council) was recorded regarding a specific nutrition policy issue. 
Table 5. Specific nutrition related issues documented in health ministers' diaries (January 2013-June 2018).

\begin{tabular}{|c|c|c|c|}
\hline Minister & Issue & Interest Group & Date \\
\hline \multirow{4}{*}{$\begin{array}{l}\text { QLD Health } \\
\text { Minister ALP }\end{array}$} & $\begin{array}{c}\text { School } \\
\text { Breakfast Program }\end{array}$ & YMCA & $\begin{array}{c}\text { August } 2015 \\
\text { September } 2016\end{array}$ \\
\hline & Childhood Obesity & Happy Health Kids NFP & November 2015 \\
\hline & Cooking Skills & $\begin{array}{l}\text { Jamie's Ministry of } \\
\text { Food Program }\end{array}$ & March 2016 \\
\hline & Diabetes prevention & Diabetes QLD & Oct 2017 \\
\hline \multirow{6}{*}{$\begin{array}{l}\text { Health Minister } \\
\text { QLD LNP }\end{array}$} & Anti-obesity program & None & October 2013 \\
\hline & Junk food advertising & None & $\begin{array}{l}\text { March } 2013 \\
\text { April } 2013\end{array}$ \\
\hline & $\begin{array}{l}\text { Anti-obesity } \\
\text { multicultural } \\
\text { communities }\end{array}$ & $\begin{array}{l}\text { Ethnic Communities } \\
\text { Council of Queensland }\end{array}$ & March 2013 \\
\hline & $\begin{array}{l}\text { Front-of-pack } \\
\text { food labelling }\end{array}$ & None & December 2013 \\
\hline & Cooking Skills & $\begin{array}{l}\text { Jamie's Ministry of } \\
\text { Food Program }\end{array}$ & May 2014 \\
\hline & Cooking skills & $\begin{array}{l}\text { Queensland Country } \\
\text { Women's Assoc. }\end{array}$ & December 2014 \\
\hline \multirow{4}{*}{ Health Minister NSW } & Cooking Skills & $\begin{array}{l}\text { Jamie's Ministry of } \\
\text { Food Program }\end{array}$ & June 2015 \\
\hline & Aboriginal Nutrition & Newcastle University & $\begin{array}{l}\text { August } 2015 \\
\text { July } 2016\end{array}$ \\
\hline & National Nutrition Week & Nutrition Australia & July 2017 \\
\hline & $\begin{array}{l}\text { Healthy Choices in } \\
\text { Health Facilities Policy }\end{array}$ & $\begin{array}{c}\text { Australian } \\
\text { Beverages Council }\end{array}$ & July 2017 \\
\hline \multirow{2}{*}{$\begin{array}{l}\text { NSW Assistant } \\
\text { Health Minister }\end{array}$} & Obesity & Obesity Support Council & September 2014 \\
\hline & Food preservatives & Citizen & October 2015 \\
\hline
\end{tabular}

\section{Discussion}

The data in this study were obtained from unique datasets that had not been previously systematically analysed. It is likely, however, that the diaries we have analysed do not capture all the interactions that ministers undertake and we have no way of knowing how closely the diaries represent a minister's actual day. The level of detail provided in QLD provides a more complete representation than in NSW, where diaries often have days with no entries at all ( $n=609$ days, $64 \%$ of NSW health ministers' days). However, valuable insights are still likely to be gained from the 5025 interactions that were recorded.

\subsection{The Food Industry Is Poorly Represented}

This analysis was originally undertaken to identify whether specific interest groups were engaging regularly with state health ministers, particularly around nutrition policy issues. Despite previous evidence in Australia [4] and internationally [15,16] highlighting direct and frequent engagement of the food industry with health ministers, this was not found to be the case in the two Australian state jurisdictions in this study. There may be several reasons for this, including the limited reporting requirements for ministerial diaries (particularly for NSW), which do not capture after-hours activities, informal meetings on the phone or in person, or who ministerial advisors are meeting with. Furthermore, these groups may be meeting with more senior ministers, for example, the state premier or treasurer, 
or with other ministries related to food—-such as agriculture or trade—or with government bureaucrats. Finally, responsibility for many aspects of nutrition policy sits with the Australian government, so relationship building may be directed there. However, any significant decisions that need to be made around regulation or legislation in Australia require agreement between the Australian government together with all the states and territories, so it is surprising that more interactions were not noted. Alternatively, this lack of representation may also indicate that the ministers' diaries are not a reliable source for documenting interactions with the food industry.

\subsection{Advocacy Organisations Are Leading Engagement}

The results demonstrate high rates of interaction between ministers and advocacy organisations in comparison to business interests. This differs from the previous research conducted on this issue. Studies from the United States of America demonstrated that the majority of advocacy organisations do not engage in 'lobbying' [17]. While this study does not examine the overall proportion of advocacy organisations participating in interactions with Ministers, the higher proportion of meetings by these organisations in comparison to the business sector may signify a change in practice over time. It may also represent a willingness from ministers to engage more widely with advocacy organisations.

Medical associations, particularly the Australian Medical Association, had the greatest number of interactions with ministers. This indicates not only a high level of activism by medical associations, but also a high level of prioritisation of the medical profession by the ministers. This prioritisation corresponds with the traditional view that medicine sits at the top of the occupational hierarchy in health and is considered the cultural authority on health and illness [18]. The observed dominance and influence of the medical profession is not unique to Australia, with several international studies reporting a similar phenomenon [19-22].

Very few interest groups met with the health ministers specifically regarding nutrition issues. This lack of engagement by nutrition professionals and not-for-profit groups advocating for nutrition issues corresponds with previous research documenting the lack of direct contact with decision-makers in nutrition policy in Australia [4]. This lack of engagement could represent a lack of understanding of the policymaking process and the key role ministers play, and/or a lack of capacity from nutrition advocates in terms of time, or advocates could be prioritising targeting national ministers instead of state-based ministers [23]. However, it is important to note that interest groups may be meeting with the ministerial advisers regarding these issues, and there is no requirement to document such interactions.

\subsection{Market Solutions to Healthcare?}

For business groups, private health care services and private hospitals topped the interactions of the NSW Health Minister and the QLD Health Minister when the LNP were in power. This may signify the growing trend towards finding market solutions to healthcare, a movement that is occurring world-wide [24]. The high level of interactions with private hospital companies coincides with a growth in private hospital beds and, accordingly, government funding for private hospitals in Australia [25]. A very different approach was taken by the QLD ALP health ministers, where rugby league associations had the greatest interaction. These meetings corresponded with additional QLD government funding for the rugby league, including: AUD $\$ 1,000,000$ to the National Rugby League State of Mind program (designed to reduce stigma around mental illness through rugby league clubs) in 2016, AUD $\$ 637,500$ over two years for the improvement of rugby league facilities around QLD in 2017, and AUD $\$ 165,000$ for a children's rugby league program run by ex-players, also in 2017 [26,27]. Alternatively, these interactions may signify an awareness that the core constituents of the Labour party in QLD are working class and traditionally follow the game of rugby league, so it may be an important political strategy for the Minister to align with this popular code of football.

One final observation relates to the diary entries of the NSW Assistant Health Minister. This position had a very different range of interactions compared to the health ministers in QLD and NSW, most notably high levels of engagement with mental health organisations, homelessness charities and drug 
and alcohol charities. This increased engagement coincided with the Assistant Minister being named Minister for Mental Health and then also Minister for Women and Medical Research. This suggests that providing specificity in the ministerial title may result in higher levels of engagement with relevant interest groups than if the title is broadly 'health'.

\section{Conclusions}

We undertook this study to identify which interest groups were engaging with state health ministers in Australia, particularly around nutrition policy. Previous research suggested that the food industry would be a strong presence, but this was not the case in this study. Instead, advocates from the medical profession dominated health ministers' documented diary time, and from the business side, private hospitals and rugby league associations dominated. Poor representation was seen on nutrition issues, and there was an apparent lack of nutrition advocates interacting with the health ministers. While the lack of documented interactions with the food industry raises questions regarding the completeness of the diaries, the findings do provide valuable insight for a progressing nutrition policy. Opportunities exist for nutrition advocates to increase their level of interaction with state health ministers. This could involve building alliances with medical associations, as they are in a powerful position to advocate directly to health ministers, and there are opportunities to collaborate on mutually shared prevention issues. Ministerial diaries offer a unique dataset which, despite limitations, are important to continue to monitor. To improve insights around lobbying further datasets, political donations, for example, could be combined with this information.

Author Contributions: Conceptualization, K.C. and T.W.; methodology, K.C. and T.W.; formal analysis, K.C.; investigation, K.C.; resources, A.L.; data curation, K.C. and T.W.; writing-original draft preparation, K.C.; writing-review and editing, K.C and T.W. and A.L.; supervision, A.L.; project administration, K.C.; funding acquisition, A.L.

Funding: This research was funded by the Australian Government's Medical Research Future Fund (MRFF), grant number BP3. MRFF Funding has been provided to The Australian Prevention Partnership Centre under the MRFF Boosting Preventive Health Research Program.

Acknowledgments: We thank Jane Jaffe and Ella Parnell Harrison for assistance with coding the diaries and Megan Ferguson for her helpful comments on an earlier draft of this manuscript.

Conflicts of Interest: The authors declare no conflict of interest. The funders had no role in the design of the study; in the collection, analyses, or interpretation of data; in the writing of the manuscript, or in the decision to publish the results.

\section{References}

1. Nestle, M. Food Politics: How the Food Industry Influences Nutrition and Health, 2nd ed.; University of California Press: Berkeley, CA, USA, 2007.

2. Cullerton, K.; Donnet, T.; Lee, A.; Gallegos, D. Effective advocacy strategies for influencing government nutrition policy: A conceptual model. Int. J. Behav. Nutr. Phys. Act. 2018, 15, 83. [CrossRef] [PubMed]

3. Beyers, J.; Braun, C. Ties that count: Explaining interest group access to policymakers. J. Public Policy 2014, 34, 93-121. [CrossRef]

4. Cullerton, K.; Donnet, T.; Lee, A.; Gallegos, D. Exploring power and influence in nutrition policy in Australia. Obes. Rev. Off. J. Int. Assoc. Study Obes. 2016, 17, 1218-1225. [CrossRef] [PubMed]

5. Bellew, W.; Bauman, A.; Kite, J.; Foley, B.; Reece, L.; Thomas, M.; Mihrshahi, S.; King, L. Obesity prevention in children and young people: What policy actions are needed? Public Health Res. Pract. 2019, 29, e2901902. [CrossRef] [PubMed]

6. Roberto, C.A.; Swinburn, B.; Hawkes, C.; Huang, T.T.; Costa, S.A.; Ashe, M.; Zwicker, L.; Cawley, J.H.; Brownell, K.D. Patchy progress on obesity prevention: Emerging examples, entrenched barriers, and new thinking. Lancet 2015, 385, 2400-2409. [CrossRef]

7. Crammond, B.; Van, C.; Allender, S.; Peeters, A.; Lawrence, M.; Sacks, G.; Mavoa, H.; Swinburn, B.A.; Loff, B. The possibility of regulating for obesity prevention-Understanding regulation in the Commonwealth Government. Obes. Rev. 2013, 14, 213-221. [CrossRef] [PubMed] 
8. Swinburn, B.; Wood, A. Progress on obesity prevention over 20 years in Australia and New Zealand. Obes. Rev. 2013, 14, 60-68. [CrossRef] [PubMed]

9. Stuckler, D.; Nestle, M. Big Food, Food Systems, and Global Health. PLoS Med. 2012, 9, e1001242. [CrossRef] [PubMed]

10. Queensland Cabinet and Ministerial Directory. Ministers' Diaries to be Released Monthly [Press Release]; Queensland Cabinet and Ministerial Directory: Queensland, Australia, 2012.

11. Premier of New South Wales. M2015-05-Publication of Ministerial Diaries and Release of Overseas Travel Information NSW, Australia: Premier and Cabinet, NSW Government. 2015. Available online: https://arp. nsw.gov.au/m2015-05-publication-ministerial-diaries-and-release-overseas-travel-information (accessed on 28 September 2018).

12. Australian Bureau of Statistics. Australian Demographic Statistics; ABS: Canberra, Australia, 2018. Available online: http://www.abs.gov.au/AUSSTATS/abs@.nsf/mf/3101.0 (accessed on 20 September 2018).

13. Australian Bureau of Statistics. Australian National Accounts: State Accounts, 2016-2017; ABS: Canberra, Australia, 2017. Available online: http:/www.abs.gov.au/AUSSTATS/abs@.nsf/DetailsPage/5220.02016-17? OpenDocument (accessed on 17 November 2017).

14. Queensland Government. Cabinet Handbook: Roles and responsibilities Queensland. 2018. Available online: https:/www.premiers.qld.gov.au/publications/categories/policies-and-codes/handbooks/cabinethandbook/roles/assistant-ministers.aspx (accessed on 30 October 2018).

15. Bottemiller Evich, H. Good Food vs Big Food; Politico: London, UK, 2015.

16. Miller, D.; Harkins, C. Corporate strategy, corporate capture: Food and alcohol industry lobbying and public health. Crit. Soc. Policy 2010, 30, 564-589. [CrossRef]

17. Bass, G.; Arons, D.; Guinane, K.; Carter, M.; Rees, S. Seen but Not Heard: Strengthening Nonprofit Advocacy; The Aspen Institute: Washington, DC, USA, 2009.

18. Freidson, E. Professional Dominance: The Social Structure of Medical Care; Atherton Press: Chicago, IL, USA, 1970.

19. Heaney, M.T. Brokering Health Policy: Coalitions, Parties, and Interest Group Influence. J. Health Politics Policy Law 2006, 31, 887-944. [CrossRef] [PubMed]

20. Grossmann, M. Interest group influence on US policy change: An assessment based on policy history. Interest Groups Advocacy 2012, 1, 171-192. [CrossRef]

21. Wang, G.-X. Policy network mapping of the universal health care reform in Taiwan: An application of social network analysis. J. Asian Public Policy 2013, 6, 313-334. [CrossRef]

22. Orton, L.C.; Lloyd-Williams, F.; Taylor-Robinson, D.C.; Moonan, M.; O’Flaherty, M.; Capewell, S. Prioritising public health: A qualitative study of decision making to reduce health inequalities. BMC public health 2011, 11, 821. [CrossRef] [PubMed]

23. Cullerton, K.; Donnet, T.; Lee, A.; Gallegos, D. Playing the policy game: A review of the barriers to and enablers of nutrition policy change. Public Health Nutr. 2016, 19, 2643-2653. [CrossRef] [PubMed]

24. Krachler, N.; Greer, I. When does marketisation lead to privatisation? Profit-making in English health services after the 2012 Health and Social Care Act. Soc. Sci. Med. 2015, 124, 215-223. [CrossRef] [PubMed]

25. Australian Institute for Health and Welfare. Hospital Resources 2015-16: Australian Hospital Statistics; Australian Institute for Health and Welfare: Canberra, Australia, 2017.

26. Queensland Government. Queensland Footy Facilities Fund Brisbane: Queensland Government. 2018. Available online: https://www.qld.gov.au/recreation/sports/funding/footy-facilities (accessed on 12 October 2018).

27. NRL State of Mind. Queenslander Boost for NRL State of Mind. 2016. Available online: http://www. nrlstateofmind.com.au/latest-news/queenslander-boost-for-nrl-state-of-mind/ (accessed on 1 November 2018).

(C) 2019 by the authors. Licensee MDPI, Basel, Switzerland. This article is an open access article distributed under the terms and conditions of the Creative Commons Attribution (CC BY) license (http://creativecommons.org/licenses/by/4.0/). 